\title{
Potential for Sulfate Reduction in Mangrove Forest Soils: Comparison between Two Dominant Species of the Americas
}

\section{OPEN ACCESS}

Edited by:

Graeme W. Nicol,

L'Université de Lyon, France

Reviewed by:

Marc Gregory Dumont

University of Southampton,

United Kingdom

Tillmann Lueders,

Helmholtz Zentrum München,

Germany

Richard Devereux,

United States Environmental

Protection Agency, USA

${ }^{*}$ Correspondence:

Hendrikus J. Laanbroek

r.laanbroek@nioo.knaw.nl

Specialty section:

This article was submitted to

Terrestrial Microbiology,

a section of the journal

Frontiers in Microbiology

Received: 03 August 2016 Accepted: 03 November 2016 Published: 18 November 2016

Citation:

Balk M, Keuskamp JA and Laanbroek HJ (2016) Potential for Sulfate Reduction in Mangrove Forest Soils: Comparison between

Two Dominant Species of the Americas. Front. Microbiol. 7:1855. doi: 10.3389/fmicb.2016.01855

\begin{abstract}
Melike Balk ${ }^{1,2}$, Joost A. Keuskamp ${ }^{1,3}$ and Hendrikus J. Laanbroek ${ }^{1,3 *}$
${ }^{1}$ Department of Microbial Ecology, Netherlands Institute of Ecology-Royal Netherlands Academy of Arts and Sciences, Wageningen, Netherlands, ${ }^{2}$ Faculty of Geosciences, Utrecht University, Utrecht, Netherlands, ${ }^{3}$ Ecology and Biodiversity Group, Department of Biology, Utrecht University, Utrecht, Netherlands
\end{abstract}

Avicennia and Rhizophora are globally occurring mangrove genera with different traits that place them in different parts of the intertidal zone. It is generally accepted that the oxidizing capacity of Avicennia roots is larger than that of Rhizophora roots, which initiates more reduced conditions in the soil below the latter genus. We hypothesize that the more reduced conditions beneath Rhizophora stands lead to more active sulfatereducing microbial communities compared to Avicennia stands. To test this hypothesis, we measured sulfate reduction traits in soil samples collected from neighboring Avicennia germinans and Rhizophora mangle stands at three different locations in southern Florida. The traits measured were sulfate reduction rates (SRR) in flow-through reactors containing undisturbed soil layers in the absence and presence of easily degradable carbon compounds, copy numbers of the $d s r B$ gene, which is specific for sulfate-reducing microorganisms, and numbers of sulfate-reducing cells that are able to grow in liquid medium on a mixture of acetate, propionate and lactate as electron donors. At the tidal locations Port of the Islands and South Hutchinson Islands, steady state SRR, dsrB gene copy numbers and numbers of culturable cells were higher at the A. germinans than at the $R$. mangle stands, although not significantly for the numbers at Port of the Islands. At the non-tidal location North Hutchinson Island, results are mixed with respect to these sulfate reduction traits. At all locations, the fraction of culturable cells were significantly higher at the $R$. mangle than at the $A$. germinans stands. The dynamics of the initial SRR implied a more in situ active sulfate-reducing community at the intertidal $R$. mangle stands. It was concluded that in agreement with our hypothesis $R$. mangle stands accommodate a more active sulfate-reducing community than $A$. germinans stands, but only at the tidal locations. The differences between $R$. mangle and $A$. germinans stands were absent at the non-tidal, impounded location.

Keywords: sulfate reduction, mangroves, Avicennia germinans, Rhizophora mangle, dsrB gene

\section{INTRODUCTION}

Mangrove species inhabiting tropical and subtropical coastal zones are adapted to tidal influences on soil temperature, water content and salt concentration, and to varying degrees of anoxia (Alongi, 2008). Species-specific adaptations of propagule dispersal, salt tolerance physiology, and root zone aeration often lead to zonation of species perpendicular to the shoreline. Avicennia and Rhizophora, 
both mangrove genera with a global distribution, developed different mechanisms to adapt to stress factors imposed by the prevailing tidal regime. Due to these differences, Avicennia and Rhizophora generally form mono-specific stands at distinct positions in the tidal zone. In Florida, for example, Rhizophora mangle usually occurs lower in the intertidal zone than Avicennia germinans that can be found more at in-land sites where tidal inundation is less frequent (McKee, 1993).

In most regions, mangrove forests are characterized by high primary production (Bouillon et al., 2008; Kristensen et al., 2008). It was estimated that on average $40 \%$ of the mangrove production is decomposed in the soil, $30 \%$ is exported from the forest, $10 \%$ is stored in the soil, and $9 \%$ is consumed by herbivores (Duarte and Cebrian, 1996). Hence, a major part of primary mangrove production is decomposed locally. Microbial decomposition will depend on soil environmental conditions, which in the case of mangroves are largely governed by the prevailing tidal regime (Keuskamp et al., 2015). Aerobic microbial processes, which are thermodynamically most favorable (Laanbroek, 1990), are restricted to the first few oxygen-containing mm's of the soil as has been shown for soils covered by Avicennia marina and Rhizophora apiculata (Andersen and Kristensen, 1988; Kristensen et al., 1988, 1992, 1994). Through the presence of aerenchyma in specialized root structures, both Avicennia spp. and Rhizophora spp. are able to transfer oxygen from the air to their roots in anoxic sediments (Scholander et al., 1955) facilitating aerobic decomposition at deeper soil layers. Several observations suggest that Avicennia species generally maintain a more oxidized root zone compared to Rhizophora species (Nickerson and Thibodeau, 1985; Thibodeau and Nickerson, 1986; Alongi et al., 2000). Since the redox status in the root zone is determined by the balance between oxygen-producing and consuming processes, the more oxidized zones with Avicennia are likely due to a higher oxygen to labile carbon ratio released from the roots of this mangrove species compared to Rhizophora species.

Sulfate reduction, which is accomplished by strictly anaerobic microorganisms, is globally the second most important respiratory process after aerobic respiration involved in the decomposition of mangrove-derived soil organic matter (Kristensen et al., 2008). An earlier study by Balk et al. (2015) suggests an effect of depth on traits of the sulfate-reducing microbial community in mangrove forest soils. Potential sulfate reduction rates, copy numbers of the $d s r B$ gene, which is specific for sulfate-reducing microbes, and numbers of sulfate-reducing cells that were able to grow on a mixture of acetate, propionate and lactate were all significantly higher in samples from the reduced sub-surface layers (4-6 cm depth) than in samples from the more oxidized surface layers (0-2 cm depth). Hence, traits of the sulfate-reducing community are strongly influenced by the redox status of the soil. Assuming more reduced conditions below Rhizophora than below Avicennia stands, we hypothesize that the soil from beneath Rhizophora has higher potential sulfate reduction rates and higher numbers of sulfate-reducing microorganisms than soil from underneath Avicennia. To test this hypothesis, we collected the upper $2 \mathrm{~cm}$ of soil from beneath A. germinans and $R$. mangle stands on three locations in South
Florida that differ mutually in tidal regimes. At each location, both species were present in separated zones. Since oxygen penetrates generally only a few mm's into the soil (Andersen and Kristensen, 1988; Kristensen et al., 1988, 1992, 1994), we assumed that differences among species in the upper $2 \mathrm{~cm}$ of the soil can largely be ascribed to differences in the balance between oxygen and carbon released by the plant roots.

\section{MATERIALS AND METHODS}

\section{Study Sites}

In March 2009, soil samples were collected from monospecific stands of Avicennia germinans and Rhizophora mangle at three mangrove forest locations in southern Florida that differ mutually in total organic carbon content (Table 1). One sampling location was situated at the Port of the Islands $\left(25^{\circ} 56^{\prime} \mathrm{N}\right.$ and $\left.81^{\circ} 30^{\prime} \mathrm{W}\right)$ in Collier County on the east coast of the Gulf of Mexico, one location near Jensen Beach $\left(27^{\circ} 17^{\prime} \mathrm{N}\right.$ and $\left.80^{\circ} 13^{\prime} \mathrm{W}\right)$ in Martin County on South Hutchinson Island, and one location near Fort Pierce $\left(27^{\circ} 28^{\prime} \mathrm{N}\right.$ and $\left.80^{\circ} 18^{\prime} \mathrm{W}\right)$ in St. Lucie County on North Hutchinson Island. North and South Hutchinson Islands are part of a range of barrier islands sheltering the Indian River lagoon from the North Atlantic Ocean. Both locations are situated on the land side of the islands along the lagoon. At the moment of sampling, the mangrove forest at North Hutchinson Island was impounded and tidal influences were restricted (Verhoeven et al., 2014). The absence of tide at this location affected mostly the stands of A. germinans. At the tidal locations Port of the Islands and South Hutchinson Island, intertidal soils from $R$. mangle stands were collected from the seaward fringes, while supratidal soils from A. germinans were sampled more from the interior of the forests. In all cases, soils were collected from mature stands with an average tree height of more than $2 \mathrm{~m}$. The soil samples were taken close to the aerial roots of the trees. Replicate samples from 0 to $2 \mathrm{~cm}$ depth were collected within an area of $1 \mathrm{~m}^{2}$ and transported to the laboratory on ice.

\section{Determination of Sulfate Reduction Rates}

Sulfate reduction rates were determined in the flow-through reactors (FTRs) as described before (Balk et al., 2015). Shortly, the incubation of intact soil layers ran in these reactors at a constant rate of $1 \mathrm{ml} \mathrm{h}^{-1}$ in a temperature-controlled room at $20-22^{\circ} \mathrm{C}$. To maintain anoxic conditions throughout the experiments, inflow solutions and connecting tubing were purged with argon and the incubations were performed in the dark to avoid oxygen production by photosynthesis. Before the start of the incubation experiments, reactors were flushed with a salt solution containing various concentrations of $\mathrm{NaCl}$ that match the salt concentrations measured at the sampling sites (Table 1). Flushing with salt solutions made it also possible to establish the time it takes a solution to move from the bottom to the top of the soil in the reactor. These so-called breakthrough times for Port of the Islands, South Hutchinson Island and North Hutchinson Island were 65,61 , and $52 \mathrm{~h}$ for the Avicennia soils, respectively, and 69,58 , and $52 \mathrm{~h}$ for the corresponding Rhizophora soils. These 
TABLE 1 | Characteristics of mangrove forest soil samples collected from Florida, USA.

\begin{tabular}{|c|c|c|c|c|c|c|}
\hline \multirow{2}{*}{$\begin{array}{l}\text { Mangrove species } \\
\text { Location }\end{array}$} & \multicolumn{3}{|c|}{ Avicennia germinans } & \multicolumn{3}{|c|}{ Rhizophora mangle } \\
\hline & $\begin{array}{l}\text { Port of the } \\
\text { Islands }\end{array}$ & $\begin{array}{l}\text { South Hutchinson } \\
\text { Island }\end{array}$ & $\begin{array}{l}\text { North Hutchinson } \\
\text { Island }\end{array}$ & $\begin{array}{l}\text { Port of the } \\
\text { Islands }\end{array}$ & $\begin{array}{l}\text { South Hutchinson } \\
\text { Island }\end{array}$ & $\begin{array}{l}\text { North Hutchinson } \\
\text { Island }\end{array}$ \\
\hline Pore water salinity (g/L) & 69.0 & 41.0 & 94.5 & 38.5 & 37.0 & 57.0 \\
\hline Pore water pH & 7.7 & 5.7 & 7.5 & 7.4 & 7.4 & 6.7 \\
\hline Mean particle size (DV50ª) & 83.9 & 91.5 & 156.7 & 86.5 & 115.8 & 291.7 \\
\hline Total organic carbon (\% dw) & 26.2 & 26.0 & 3.5 & 22.3 & 13.0 & 6.1 \\
\hline
\end{tabular}

as volume-based mean diameter.

breakthrough times correlated well $\left(R^{2}=0.765\right)$ with the total carbon contents presented in Table 1. During the first $90 \mathrm{~h}$ of the incubation experiment, the inflow solutions contained $4 \mathrm{mM}$ sodium sulfate, defined concentrations of $\mathrm{NaCl}$ and no electron donor. In order to determine the effect of easily available organic carbon on sulfate reduction rates, both sodium acetate $(10 \mathrm{mM})$ and sodium lactate $(10 \mathrm{mM})$ were supplied after $90 \mathrm{~h}$, while sodium sulfate was increased to $8 \mathrm{mM}$ to fulfill the demand for extra oxidant capacity. Sulfate concentrations were measured by ion chromatography using a Dionex DX120 (Water, Milford, MA, USA) with an IonPac ICE-AS6 column and Anion-ICE Micro Membrane II suppressor. Steady-state sulfate reduction rates (SRR) were calculated as described before (Balk et al., 2015).

\section{DNA Extraction}

Chromosomal DNA was isolated from the soils by a modification of the DNA isolation procedure as described previously by Zhou et al. (1996). DNA was further purified using the DNA Clean \& Concentrator kit (Zymo Research, Orange, CA, USA). The quantity and quality of the extracted DNA were analyzed by spectrophotometry using a ND-1000 spectrophotometer (NanoDrop Technologies, Wilmington, DE, USA) and by agarose gel electrophoresis. The genomic DNA was stored at $-20^{\circ} \mathrm{C}$ for further analyses.

\section{qPCR Amplification}

qPCR amplification for sulfate-reducing prokaryotes targeting on the $d s r B$ gene was performed in a total volume of $20 \mu \mathrm{l}$ with the primer pair DSRp2060F and DSR4R (Geets et al., 2006) on a Rotor-Gene 3000 (Corbett Research, QIAGEN, Valencia, CA, USA). Each PCR mixture was made using a CAS-1200 pipetting robot (Corbett Research, QIAGEN, Valencia, CA, USA) and contained $3 \mu \mathrm{l}$ diluted template, $10 \mu$ l Absolute ${ }^{\mathrm{TM}}$ QPCR SYBR Green Mix (Thermo Scientific, Epsom, UK), $0.4 \mu \mathrm{l}$ of each primer $(10 \mu \mathrm{M})$ and $1 \mu \mathrm{l}$ Bovine Serum Albumin (BSA; $20 \mathrm{mM}$ ). The qPCR procedure was as follows: $10 \mathrm{~s}$ at $95^{\circ} \mathrm{C}$ for initial denaturation, 45 cycles of $20 \mathrm{~s}$ at $95^{\circ} \mathrm{C}, 30 \mathrm{~s}$ at $56^{\circ} \mathrm{C}$, and $45 \mathrm{~s}$ at $72^{\circ} \mathrm{C}$. At each cycle, fluorescence was obtained at $84^{\circ} \mathrm{C}$. A melting curve was performed from $55^{\circ} \mathrm{C}$ to $99^{\circ} \mathrm{C}$ to confirm PCR product specificity. Purified PCR products from extracted DNA originating from the same soil samples, generated with the same primer set and cloned into the pGEM-T Easy Vector (Promega, Madison, WI, USA) were used for the production of the standard curve. In order to get specific products and avoid inhibition, dilution series were made of the soil DNA solution to test for inhibition and set a 100 -fold dilution as the final template. The amplification efficiency ranged from 98 to $104 \%$ with $R^{2}$ values greater than 0.99 .

\section{Enumeration of Sulfate-Reducing Microorganisms Able to Grow on a Mixture of Acetate, Propionate, and Lactate}

A Most Probable Number (MPN) assay was applied for enumeration of sulfate-reducing microorganisms able to grow on a mixture of acetate, propionate and lactate (APL medium). Briefly, soil was re-suspended in phosphate-buffered saline $(\mathrm{pH}$ 7.4) in a soil to buffer ratio of $1: 6$ and shaken for $2 \mathrm{~h}$. Subsequently, 10-fold dilutions were made in microtiter plates containing a minimal salt medium (Widdel and Bak, 1992) supplemented with a mix of acetate, propionate and lactate (15 mM each) as electron donors. Sodium sulfate $(20 \mathrm{mM})$ was provided as the electron acceptor. Sodium thioglycolate $(0.5 \mathrm{mM})$ was added as reducing agent and iron sulfate $(0.2 \mathrm{mM})$ as indicator for the occurrence of sulfate reduction. The formation of black iron sulfide precipitates was indicative for sulfate reduction. The microtiter plates were incubated for 3 months at $25^{\circ} \mathrm{C}$ in anaerobic incubation bags (Anaerocult ${ }^{\circledR}$ A mini, Merck, Darmstadt, Germany). Based on the number of positive wells, the most probable numbers and related confidence limits were calculated using standard tables (Rowe et al., 1977).

\section{Statistics}

The obtained data were fitted to (mixed) linear models in $\mathrm{R}$ 3.2.3 ( $\mathrm{R}$ Core Team, 2015) with site as a random factor where appropriate. Normality and homoscedasticity of residuals were visually assessed and confirmed by ShapiroWilk and Levene's tests, respectively. Where necessary, log transformations were applied prior to analysis. Overall effects were tested for significance using ANOVA with type II sum of squares using car 2.0-22 (Fox and Weisberg, 2011), while pairwise comparisons were conducted using Tukey's HSD as implemented in the multcomp 1.4-6 package (Hothorn et al., 2008). Due to the commonly observed interactive effect of plant species and locations, the effects of both fixed variables on the sulfate reduction traits were tested separately. 

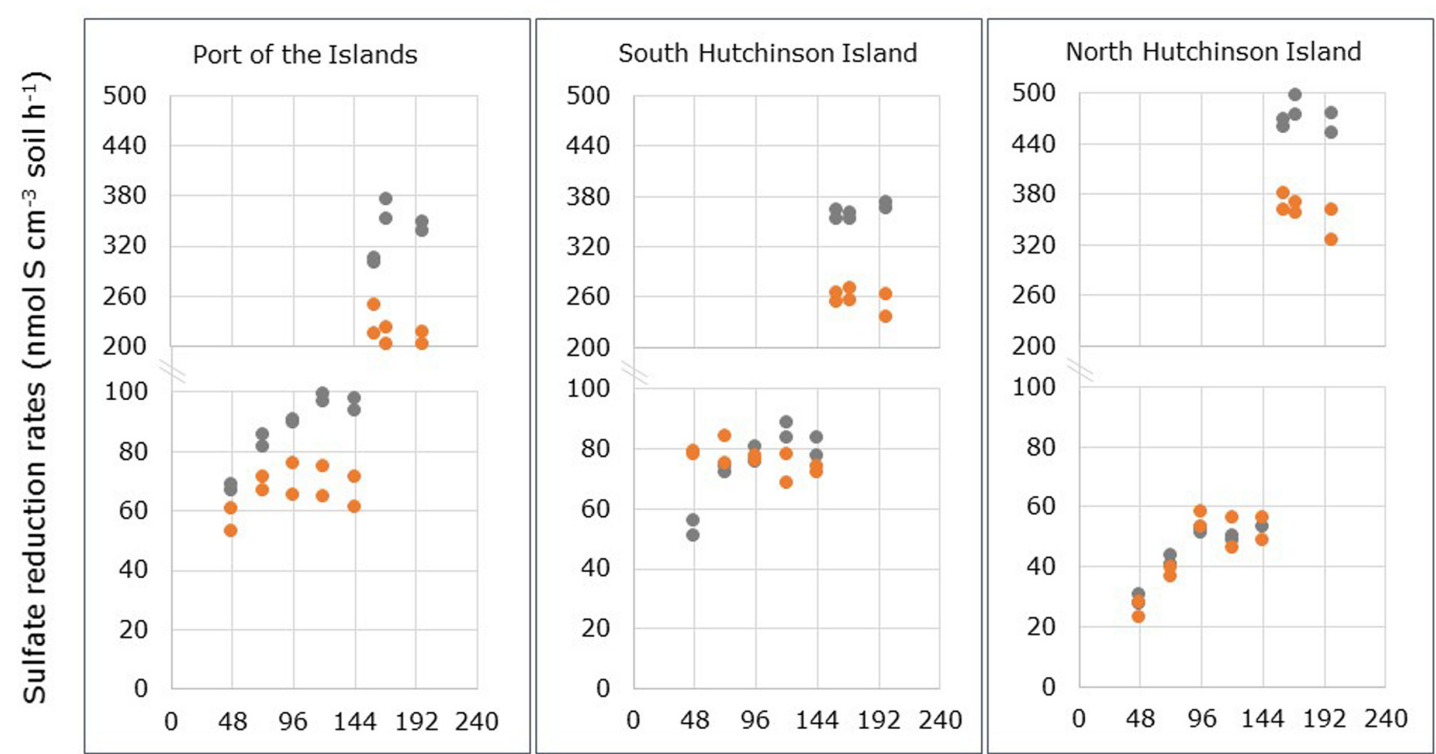

Time (hours)

FIGURE 1 | Sulfate reduction rates (SRR) measured in through-flow reactors containing the top $2 \mathrm{~cm}$ of intact soil samples collected from Avicennia germinans (gray dots) and Rhizophora mangle stands (orange dots) at Port of the Islands, South Hutchinson Island and North Hutchinson Island. Note the split $Y$-axes for the points presented after $144 \mathrm{~h}$.

\section{RESULTS}

\section{Potential Sulfate Reduction Rates}

Differences between sulfate concentrations in- and outflowing the FTRs filled with undisturbed mangrove soils reflect the activity of sulfate-reducing microorganisms in these soils. Figure 1 presents the SRR measured in the FTRs. The increase in rates after $144 \mathrm{~h}$ was due to the amendment of easily degradable carbon sources (i.e., acetate and lactate) to the inflowing medium. These carbon sources were added $90 \mathrm{~h}$ after the start of the incubation. Delay between amendment and observation of its effects was determined by the breakthrough time, which is the time needed for the solution to pass the entire reactor. In the nonamended incubations of soils samples from Port of the Islands and South Hutchinson Island, the reactors reached steady state SRR within 96 and $48 \mathrm{~h}$, respectively, for $R$. mangle soils, while soils from A. germinans required $120 \mathrm{~h}$ to reach steady state SRR. Such a difference between A. germinans or R. mangle stands was not observed in North Hutchinson Island: Soils from both species required $96 \mathrm{~h}$ to reach steady state rates.

For the calculation of average steady state SRR two periods were used: One from 96 to $144 \mathrm{~h}$ measured in the absence of added carbon sources, and one from 160 to $198 \mathrm{~h}$ determined in the presence of added acetate plus lactate. The results are presented in Table 2. When only the natural carbon sources were available, steady state SRR were significantly higher in soil samples from A. germinans stands than in soil samples from $R$. mangle stands for the locations Port of the Islands and South Hutchinson Island ( $p<0.001$ and $p<0.01$, respectively), while in samples from North Hutchinson Island no significant differences were observed between stands from both plant species (Supplementary Table S1). Sampling location had a significant effect on measured steady state SRR $(p<0.001)$. Due to interactive effects of plant species and sampling locations, the effect of location on steady state SRR was tested separately for each species (Supplementary Table S2). In $R$. mangle stands, no significant differences in SRR were observed between Port of the Islands and South Hutchinson Island, although both showed significantly higher steady state rates compared to soil from North Hutchinson Island. In soils from A. germinans stands, steady state SRR in the absence of added organic compounds differed significantly between locations: North Hutchinson Island $<$ South Hutchinson Island $<$ Port of the Islands. Hence with both mangrove species, steady state SRR were significantly lower in samples from North Hutchinson Island.

The rate differences between A. germinans- and R. manglederived soils became more pronounced by addition of extra electron donors (Figure 2; Table 2). Steady state SRR were consistently higher in soil samples from A. germinans stands than in samples from $R$. mangle stands (Supplementary Table S1). Sampling location had also a significant effect on these rates $(p<0.001)$. For soils from $R$. mangle and A. germinans stands, steady state SRR increased significantly between locations in the same order: Port of the Islands < South Hutchinson Island $<$ North Hutchinson Island (Supplementary Table S2).

\section{Numbers of Sulfate-Reducing Microorganisms}

Numbers of sulfate-reducing microorganisms in the mangrove soil were enumerated in two ways, i.e., by determining the copy 
TABLE 2 | Steady-state sulfate reduction rates (SRR) (nMol S cm$~_{-3} \mathrm{~h}^{-1}$ ) measured in non-carbon-amended and in carbon-amended flow-through reactors (FTRs) containing the upper $2 \mathrm{~cm}$ of soils collected from Avicennia germinans or Rhizophora mangle stands.

\begin{tabular}{|c|c|c|c|c|c|c|}
\hline & \multicolumn{3}{|c|}{ Non-carbon amended reduction rates } & \multicolumn{3}{|c|}{ Carbon-amended reduction rates } \\
\hline & $\begin{array}{l}\text { Port of the } \\
\text { Islands }\end{array}$ & $\begin{array}{l}\text { South Hutchinson } \\
\text { Island }\end{array}$ & $\begin{array}{l}\text { North Hutchinson } \\
\text { Island }\end{array}$ & $\begin{array}{l}\text { Port of the } \\
\text { Islands }\end{array}$ & $\begin{array}{l}\text { South Hutchinson } \\
\text { Island }\end{array}$ & $\begin{array}{l}\text { North Hutchinson } \\
\text { Island }\end{array}$ \\
\hline Avicennia germinans & 97 & 83 & 49 & 336 & 361 & 471 \\
\hline Rhizophora mangle & 68 & 73 & 52 & 217 & 257 & 359 \\
\hline
\end{tabular}

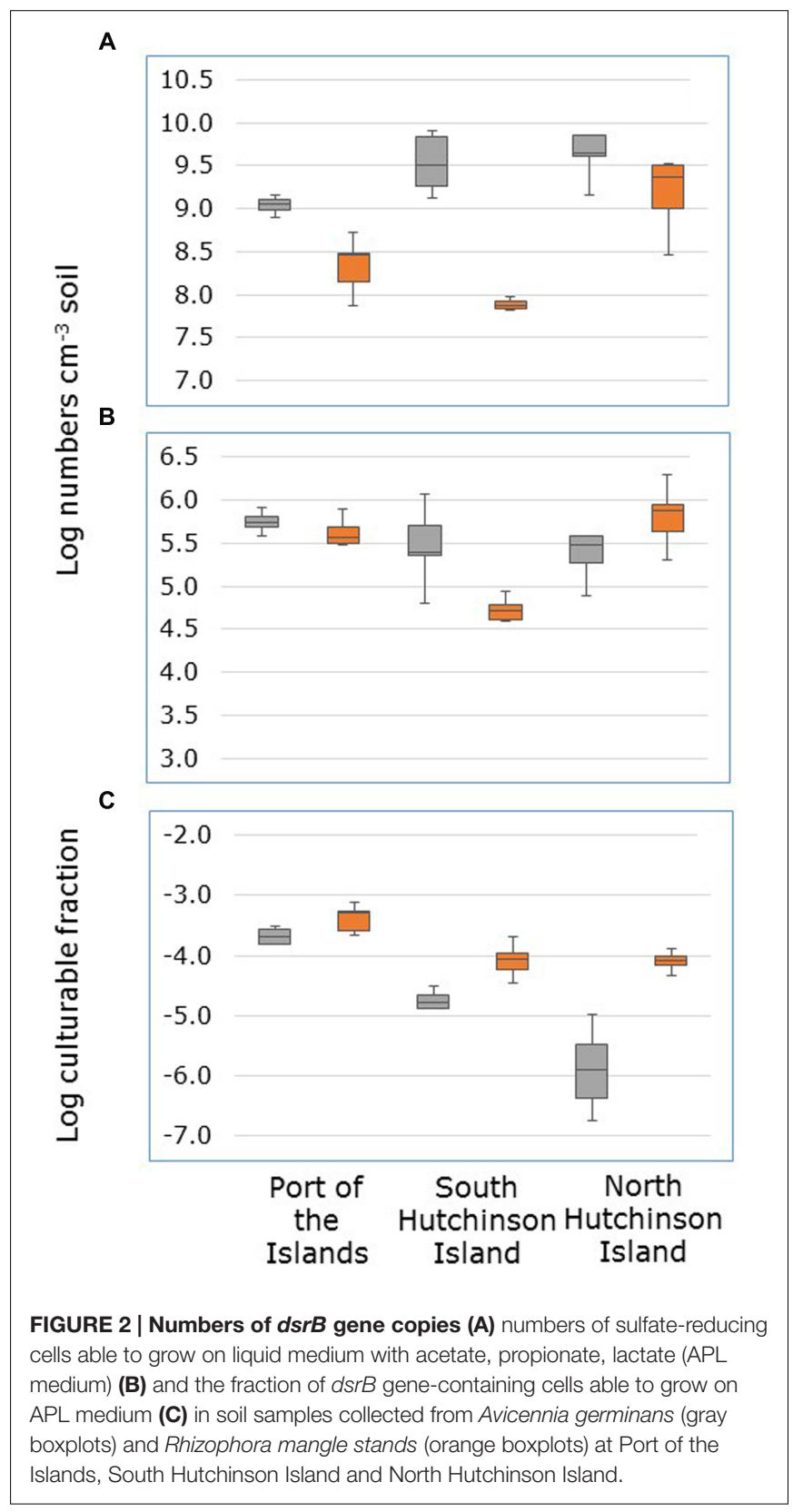

numbers of the $d s r B$ gene and by establishing the number of cells able to grow in APL medium by an MPN method. Numbers of these latter cells were on average 96000 times lower than the copy numbers of the $d s r B$ gene.
Copy numbers of the $d s r B$ gene were on average higher in soil samples from A. germinans stands than from $R$. mangle stands (Figure 2A). However, this was only significant for samples collected at South Hutchinson Island (Supplementary Table S1). Due to the interactive effects of plant species and sampling locations, the effect of sampling location on $d s r B$ gene copy numbers was tested separately for both mangrove species. For $R$. mangle stands, gene copy numbers were significantly higher in samples from North Hutchinson Island than in samples from Port of the Islands and South Hutchinson Island that did not significantly differ from each other (Supplementary Table 2). For A. germinans stands, gene copy numbers were significantly lower in samples from Port of the Islands than in samples from South and North Hutchinson Island that did not significantly differ from each other.

The effect of numbers of cells that grew in APL medium was also dependent on sampling location (Figure 2B). Only in soil samples from South Hutchinson Island, significantly higher cell numbers were observed in samples from A. germinans stands than in samples from $R$. mangle stands (Supplementary Table S1). At the other locations, numbers of cells able to grow on a mixture of acetate, propionate, and lactate did not differ significantly between A. germinans and R. mangle stands. For A. germinans stands sampling location had no significant effect on the number of such cells, but for $R$. mangle stands these numbers were significantly higher at North Hutchinson Island than at Port of the Islands and South Hutchinson Island, which did not differ significantly from each other (Supplementary Table S2).

Both plant species and sampling location had a significant effect on the fraction of $d s r B$-containing cells that were able to grow in APL medium (Supplementary Table S3). This fraction was higher in the R. mangle stand than in the A. germinans stands, and higher at Port of the Islands than at the other locations (Figure 2C).

\section{DISCUSSION}

Based on the generally accepted idea that Rhizophora soils are more reduced than Avicennia soils, we hypothesized that sulfate reduction traits such as community size and activity would be more manifest in soils from Rhizophora stands than in soils from Avicennia stands. A number of observations seemed to disprove the hypothesis. Potential steady state reduction rates, copy numbers of the $d s r B$ gene, and numbers of culturable cells were all significantly higher values in samples obtained from A. germinans stands than in samples from $R$. mangle 
stands, at least at the tidal locations Port of the Islands and South Hutchinson Island. Then the question arises what causes the unexpected findings of higher sulfate reduction traits in A. germinans stands than in $R$. mangle stands, which are assumed to be more reduced than the Avicennia locations?

Was the original assumption correct that Avicennia is able to maintain a more oxidized root zone than Rhizophora? By a series of gas exchange experiments Scholander et al. (1955) showed that both Avicennia nitida (synonymous with A. germinans) and $R$. mangle are able to supply their aerenchymatous roots with oxygen from the atmosphere, albeit with different temporal cycles. Both $A$. nitida and $R$. mangle showed diurnal cycles with the highest oxygen concentrations at day time. However, $A$. nitida growing in the tidal zone revealed also tidal cycles with the highest oxygen concentrations during low tide. Thibodeau and Nickerson (1986) measured a decreasing redox potential in the soil with an increasing distance to A. germinans trees, whereas the opposite, i.e., increasing redox potential with increasing distance to the trees, was observed with $R$. mangle. As shown in another publication by Nickerson and Thibodeau (1985), the root zone-oxidizing capacity of A. germinans may lead to growth of this species in more sulfide-rich soils than $R$. mangle. In contrast to A. germinans, $R$. mangle is not able to lower the sulfide concentration of the surrounding soil. In a study on below-ground decomposition of organic matter in mangrove forest dominated by Avicennia marina or Rhizophora stylosa, Alongi et al. (2000) observed lower redox potential in the upper soil layers of $R$. stylosa stands than in the upper soil layers of A. marina stands, even when both species grew in the same tidal zone. In only one case studied by Alongi et al. (2000), a lower redox potential was observed in the upper layers of an A. marina stand. The authors suggested that such a difference in behavior between the species may be due to differential exposure to wave action and perhaps to differences in flooding and drainage cycles. So in general, we have no reason to assume that our $R$. mangle stands are less reduced than our A. germinans stands. The more so because the intertidal $R$. mangle stands at the tidal locations Port of the Islands and South Hutchinson Island were flooded twice daily, whereas the supratidal A. germinans stands were flooded seldom. With respect to the non-tidal stands in the impounded mangrove forest of North Hutchinson Island, the $R$. mangle stands were always wetter than the A. germinans stands. Another indication of more oxidized conditions at the A. germinans stands in our study may the higher salinities measured pair-wise in the A. germinans and $R$. mangle stands at the three locations. A higher salinity reflects a higher degree of evapotranspiration and consequently a higher degree of air drawn into the soil.

Might the lower $d s r B$ gene copy numbers observed at the tidal $R$. mangle stands be explained by inhibition of the qPCR procedure by the presence of inhibiting compounds? A generally low nutrient content combined with a relatively high content of condensed tannins and phenolic compounds, lead generally to a lower carbon decomposition rate and consequently to more organic carbon accumulation at Rhizophora stands than at Avicennia stands (Robertson, 1988; McKee and Faulkner, 2000; Middleton and McKee, 2001; Erickson et al., 2004; Kristensen et al., 2008; Galeano et al., 2010; Lima and Colpo, 2014). The
A. germinans and R. mangle stands have been selected pairwise at three locations in mutually remote regions. These pairwise stands showed always a higher total carbon content at the A. germinans than at the $R$. mangle stands, except at the impounded, non-tidal location of North Hutchinson. However, we cannot exclude that certain carbon compounds specifically present at $R$. mangle stands have affected the enumeration of $d s r B$ gene copies by qPCR negatively. An argument against a possible inhibition of the qPCR enumeration by organic compounds present at the $R$. mangle stands, might be the distribution of culturable cell numbers at the different locations that show the same trends as observed with $d s r B$ gene copies. Finally, the trend of higher numbers at $A$. germinans stands compared to $R$. mangle stands, reflects the higher potential SRR measured in samples from A. germinans stands.

Were the levels of $d s r B$ gene copy numbers very different form numbers determined in other studies? Irrespective of A. germinans or $R$. mangle, the median abundance of the $d s r B$ gene we observed at the different stands varied between $7.5 \times 10^{7}$ and $4.4 \times 10^{9}$ copies per $\mathrm{cm}^{3}$, which is slightly above the range we found in the carbon-poor A. marina soils at the Red Sea coast (Balk et al., 2015). At the upper $5 \mathrm{~cm}$ of an oilcontaminated, Brazilian mangrove soil, Andrade et al. (2012) observed $3.6 \times 10^{8} d s r B$ gene copies per g soil (Andrade et al., 2012). In other contaminated mangrove soils in Brazil, the $d s r B$ gene copy numbers varied from $7.9 \times 10^{4}$ to $2.0 \times 10^{5}$ per $g$ soil (Varon-Lopez et al., 2014). These last numbers are lower than the other numbers from mangrove soils, but Varon-Lopez et al. (2012) mixed the upper $30 \mathrm{~cm}$ of the soil before they started their analyses. From the work of Andrade et al. (2012) it is known that $d s r B$ gene copy numbers decline with depth. The numbers of $d s r B$ gene copies found in our study were at the same range as found for example in estuarine sediments (Kondo et al., 2004) and in paddy soil (Liu et al., 2009).

A striking observation was the significantly larger fraction of culturable cells in samples from the $R$. mangle stands than in samples from the $A$. germinans stands, although absolute numbers of $d s r B$-containing and growing cells were larger at the A. germinans stands. A larger fraction of culturable cells might be explained by differences in community composition, but this was not determined in this study. In our former study on sulfatereducing communities at the Red Sea coast we found a higher fraction of culturable cells in the deeper soil layers than in the surface layers, but we were not able to relate this to differences in genus diversity and to differences in functional diversity (Balk et al., 2015). So most likely, the higher fraction of culturable cells mimicked more active sulfate-reducing communities at the intertidal $R$. mangle stands.

The presence of a more active sulfate-reducing community present at intertidal $R$. mangle stands than at supratidal A. germinans stands may also be inferred from the differences in time required to obtain steady state rates as was observed during the measurements of potential sulfate-reducing activities. At the tidal locations, samples from $R$. mangle stands collected at Port of the Islands and South Hutchinson Island required 96 and $48 \mathrm{~h}$, respectively, before steady state rates were obtained, while the corresponding time for samples from A. germinans stands 
amounted to $120 \mathrm{~h}$ for both locations. No difference with respect to reaching steady state SRR was observed between $R$. mangle and A. germinans samples collected at the impounded, nontidal location of North Hutchinson Island. The time required to reactivate the cells from the more oxidized stands may be due to the establishment of anoxic conditions upon starting the measurements in the FTR's. Sulfate-reducing microorganisms have been observed in oxic parts of estuarine and lake sediments before (Laanbroek and Pfennig, 1981; Sass et al., 1997). Sulfatereducing strains isolated from oxic sediment layers revealed a higher oxygen tolerance and capacity of oxygen respiration than strains originating from anoxic sediment layers (Sass et al., 1997). In this latter study, no sulfate reduction was observed under oxic conditions because oxygen was preferentially reduced. All strains of a diverse group of sulfate-reducing isolates were able to oxidize lactate and even to oxidize sulfide in the presence of oxygen thereby creating again anoxic conditions (Sass et al., 2002).

The impounded, non-tidal location at North Hutchinson Island reacted also more strong than the tidal stations to the addition of acetate and lactate as electron donors to the FTR's used for determining potential SRR. This may be explained by a different community present in the non-tidal stands or on repression of sulfate reduction by organic compounds present in the tidal stands. With respect to this latter explanation: The supratidal $A$. germinans stands at the tidal locations showed a more intense effect in the FTR's upon the addition of acetate and lactate than the intertidal $R$. mangle stands, while these tidal stands contained more organic carbon than the samples from the non-tidal North Hutchinson Island location. Hence, it seems that more oxidized habitats at the non-tidal stations and at the supratidal A. germinans stands at the tidal stations contain a community able to react more intense of the addition of acetate and lactate once they have been activated by creating anoxic conditions in the reactors.

\section{CONCLUSION}

Firstly, when potential sulfate-reduction rates and total numbers of $d s r B$ gene copies and of culturable cells are not the most reliable indicators for active sulfate-reducing communities, but when the dynamics of SRR measured during the initial period in the FTR's and the size of the fraction of culturable cells are, then the tidal

\section{REFERENCES}

Alongi, D. M. (2008). Mangrove forests: resilience, protection from tsunamis, and responses to global climate change. Estuar. Coast. Shelf Sci. 76, 1-13. doi: 10.1016/j.ecss.2007.08.024

Alongi, D. M., Tirendi, E., and Clough, B. F. (2000). Below-ground decomposition of organic matter in forests of the mangroves Rhizophora stylosa and Avicennia marina along the arid coast of Western Australia. Aquat. Bot. 68, 97-122. doi: 10.1016/S0304-3770(00) 00110-8

Andersen, F. O., and Kristensen, E. (1988). Oxygen microgradients in the rhizosphere of the mangrove Avicennia marina. Mar. Ecol. Progress Ser. 44, 201-204. doi: 10.3354/meps044201

Andrade, L. L., Leite, D. C. A., Ferreira, E. M., Ferreira, L. Q., Paula, G. R., Maguire, M. J., et al. (2012). Microbial diversity and anaerobic hydrocarbon degradation stands of $R$. mangle accommodate a more active sulfate-reducing community than the stands of $A$. germinans, and we cannot disprove our hypothesis.

Secondly, the supratidal A. germinans stands at the tidal locations and the A. germinans and $R$. mangle stands at the impounded, non-tidal location accommodate apparently a sulfate-reducing community that is able to survive oxidized conditions.

\section{AUTHOR CONTRIBUTIONS}

MB collected the samples, performed the analyses, took part in the discussions and participated in writing of the manuscript. JK performed the statistical analyses, took part in the discussions and participated in writing of the manuscript. HL collected the samples, took part in the discussions and participated in writing of the manuscript.

\section{ACKNOWLEDGMENTS}

We would like to acknowledge Drs. Mariet Hefting, Jos Verhoeven, and Dennis Whigham for their assistance during the collection of the samples. We also want to acknowledge the help we obtained from Dr. Valery Paul, Mr. Woody Lee, and staff of the Smithsonian Marine Station at Fort Pierce. The research has been funded by the King Abdullah University of Science and Technology (KAUST) (www.kaust. edu.sa) Center-in-Development Award to Utrecht University via the KAUST Global Research Partnership and by the Netherlands Organization for Scientific Research (NWO)/User Support Program Space Research (Project no. ALW-GO/12-43). This is publication number 6192 of the Netherlands Institute of Ecology and publication number 1046 of the Smithsonian Marine Station.

\section{SUPPLEMENTARY MATERIAL}

The Supplementary Material for this article can be found online at: http://journal.frontiersin.org/article/10.3389/fmicb. 2016.01855/full\#supplementary-material

potential in an oil-contaminated mangrove sediment. BMC Microbiol. 12:186. doi: 10.1186/1471-2180-12-186

Balk, M., Keuskamp, J. A., and Laanbroek, H. J. (2015). Potential activity, size, and structure of sulfate-reducing microbial communities in an exposed, grazed and a sheltered, non-grazed mangrove stand at the red sea coast. Front. Microbiol. 6:1478. doi: 10.3389/fmicb.2015.01478

Bouillon, S., Borges, A. V., Castaneda-Moya, E., Diele, K., Dittmar, T., Kristensen, E., et al. (2008). Mangrove production and carbon sinks: a revision of global budget estimates. Global Biochem. Cycles 22:GB2013. doi: 10.1029/2007GB003052

Duarte, C. M., and Cebrian, J. (1996). The fate of marine autotrophic production. Limnol. Oceanogr. 41, 1758-1766. doi: 10.1038/ismej.2016.6

Erickson, A. A., Bell, S. S., and Dawes, C. J. (2004). Does mangrove leaf chemistry help explain crab herbivory patterns? Biotropica 36, 333-343. doi: $10.1646 / 03194$ 
Fox, J., and Weisberg, S. (2011). An R Companion to Applied Regression. Thousand Oaks, CA: Sage Publications.

Galeano, E. G., Pineda, J. E. M., and Calderon, J. H. M. (2010). Effect of the substrate on the litter decomposition in three mangrove species in the Biosphere Reserve Seaflower, Colombian Caribbean. Caldasia 32, 411-424.

Geets, J., Borremans, B., Diels, L., Springael, D., Vangronsveld, J., van der Lelie, D., et al. (2006). DsrB gene-based DGGE for community and diversity surveys of sulfate-reducing bacteria. J. Microbiol. Methods 66, 194-205. doi: 10.1016/j.mimet.2005.11.002

Hothorn, T., Bretz, F., and Westfall, P. (2008). Simultaneous inference in general parametric models. Biom. J. 50, 346-363. doi: 10.1002/bimj.200810425

Keuskamp, J. A., Hefting, M. M., Dingemans, B. J. J., Verhoeven, J. T. A., and Feller, I. C. (2015). Effects of nutrient enrichment on mangrove leaf litter decomposition. Sci. Total Environ. 508, 402-410. doi: 10.1016/j.scitotenv.2014.11.092

Kondo, R., Nedwell, D. B., Purdy, K. J., and Silva, S. D. (2004). Detection and enumeration of sulphate-reducing bacteria in estuarine sediments by competitive PCR. Geomicrobiol. J. 21, 145-157. doi: 10.1080/01490450490275307

Kristensen, E., Andersen, F. O., and Kofoed, L. H. (1988). Preliminary assessment of benthic community metabolism in a southeast Asian mangrove swamp. Mar. Ecol. Progress Ser. 48, 137-145. doi: 10.3354/meps048137

Kristensen, E., Bouillon, S., Dittmar, T., and Marchand, C. (2008). Organic carbon dynamics in mangrove ecosystems: a review. Aquat. Bot. 89, 201-219. doi: 10.1016/j.aquabot.2007.12.005

Kristensen, E., Devol, A. H., Ahmed, S. I., and Saleem, M. (1992). Preliminarystudy of benthic metabolism and sulfate reduction in a mangrove swamp of the Indus delta, Pakistan. Mar. Ecol. Progress Ser. 90, 287-297. doi: $10.3354 /$ meps090287

Kristensen, E., King, G. M., Holmer, M., Banta, G. T., Jensen, M. H., Hansen, K., et al. (1994). Sulfate reduction, acetate turnover and carbon metabolism in sediments of the Ao Nam Bor mangrove, Phuket, Thailand. Mar. Ecol. Progress Ser. 109, 245-255. doi: 10.3354/meps109245

Laanbroek, H. J. (1990). Bacterial cycling of minerals that affect plant-growth in waterlogged soils - a review. Aquat. Bot. 38, 109-125. doi: 10.1016/03043770(90)90101-P

Laanbroek, H. J., and Pfennig, N. (1981). Oxidation of short-chain fatty-acids by sulfate-reducing bacteria in fresh-water and in marine-sediments. Arch. Microbiol. 128, 330-335. doi: 10.1007/BF00422540

Lima, R. G., and Colpo, K. D. (2014). Leaf-litter decomposition of the mangrove species Avicennia schaueriana, Laguncularia racemosa and Rhizophora mangle. J. Mar. Biol. Assoc. U.K. 94, 233-239. doi: 10.1017/s0025315413001574

Liu, X. Z., Zhang, L. M., Prosser, J. I., and He, J. Z. (2009). Abundance and community structure of sulfate reducing prokaryotes in a paddy soil of southern China under different fertilization regimes. Soil Biol. Biochem. 41, 687-694. doi: 10.1016/j.soilbio.2009.01.001

McKee, K. L. (1993). Soil physicochemical patterns and mangrove species distribution - reciprocal effects. J. Ecol. 81, 477-487. doi: 10.2307/2261526

McKee, K. L., and Faulkner, P. L. (2000). Restoration of biogeochemical function in mangrove forests. Restor. Ecol. 8, 247-259. doi: 10.1046/j.1526100x.2000.80036.x
Middleton, B. A., and McKee, K. L. (2001). Degradation of mangrove tissues and implications for peat formation in Belizean island forests. J. Ecol. 89, 818-828. doi: 10.1046/j.0022-0477.2001.00602.x

Nickerson, N. H., and Thibodeau, F. R. (1985). Association between pore water sulfide concentrations and the distribution of mangroves. Biogeochemistry 1, 183-192. doi: 10.1007/bf02185041

R Core Team (2015). R: A Language and Environment for Statistical Computing. $R$ Foundation for Statistical Computing. Available at: https://www.R-project.org/

Robertson, A. I. (1988). Decomposition of mangrove leaf litter in tropical Australia. J. Exp. Mar. Biol. Ecol. 116, 235-247. doi: 10.1016/0022-0981(88) 90029-9

Rowe, R., Todd, R., and Waide, J. (1977). Microtechnique for most-probablenumber analysis. Appl. Environ. Microbiol. 33, 675-680.

Sass, A. M., Eschemann, A., Kuhl, M., Thar, R., Sass, H., and Cypionka, H. (2002). Growth and chemosensory behavior of sulfate-reducing bacteria in oxygen-sulfide gradients. FEMS Microbiol. Ecol. 40, 47-54. doi: 10.1111/j.15746941.2002.tb00935.x

Sass, H., Cypionka, H., and Babenzien, H. D. (1997). Vertical distribution of sulfate-reducing bacteria at the oxic-anoxic interface in sediments of the oligotrophic Lake Stechlin. FEMS Microbiol. Ecol. 22, 245-255. doi: 10.1111/j.1574-6941.1997.tb00377.x

Scholander, P. F., Vandam, L., and Scholander, S. I. (1955). Gas exchange in the roots of mangroves. Am. J. Bot. 42, 92-98. doi: 10.2307/2438597

Thibodeau, F. R., and Nickerson, N. H. (1986). Differential oxidation of mangrove substrate by Avicennia germinans and Rhizophora mangle. Am. J. Bot. 73, 512-516. doi: 10.2307/2444255

Varon-Lopez, M., Dias, A. C. F., Fasanella, C. C., Durrer, A., Melo, I. S., Kuramae, E. E., et al. (2014). Sulphur-oxidizing and sulphate-reducing communities in Brazilian mangrove sediments. Environ. Microbiol. 16, 845-855. doi: 10.1111/1462-2920.12237

Verhoeven, J. T. A., Laanbroek, H. J., Rains, M. C., and Whigham, D. F. (2014). Effects of increased summer flooding on nitrogen dynamics in impounded mangroves. J. Environ. Manag. 139, 217-226. doi: 10.1016/j.jenvman.2014.02.035

Widdel, F., and Bak, F. (1992). "Gram-negative mesophilic sulfatereducing bacteria," in The Prokaryotes, eds A. Balows, H. G. Trüper, M. Dworkin, W. Harder, and K. H. Schleifer (New York, NY: Springer), 3352-3378.

Zhou, J. Z., Bruns, M. A., and Tiedje, J. M. (1996). DNA recovery from soils of diverse composition. Appl. Environ. Microbiol. 62, 316-322.

Conflict of Interest Statement: The authors declare that the research was conducted in the absence of any commercial or financial relationships that could be construed as a potential conflict of interest.

Copyright (c) 2016 Balk, Keuskamp and Laanbroek. This is an open-access article distributed under the terms of the Creative Commons Attribution License (CC BY). The use, distribution or reproduction in other forums is permitted, provided the original author(s) or licensor are credited and that the original publication in this journal is cited, in accordance with accepted academic practice. No use, distribution or reproduction is permitted which does not comply with these terms. 